\title{
Program Pelatihan Pemberdayaan dan Peluang Bisnis Teh Kombucha Bagi Persaudaraan Muda-mudi Vihara Dharma Loka Kota Pekanbaru, Riau
}

\author{
Catarina Aprilia Ariestanti ${ }^{\# 1}$, Vania Angelina ${ }^{* 2}$, Verine Loerensyah ${ }^{\wedge 3}$

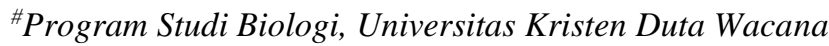 \\ Jalan Dr. Wahidin Sudirohusodo no.5-25, Yogyakarta \\ 1catarina.ariestanti@staff.ukdw.ac.id \\ *Program Studi Desain Produk, Universitas Kristen Duta Wacana \\ Jalan Dr. Wahidin Sudirohusodo no.5-25, Yogyakarta \\ 2vnianglin38@gmail.com \\ ${ }^{\wedge}$ Program Studi Manajemen, Universitas Kristen Duta Wacana \\ Jalan Dr. Wahidin Sudirohusodo no.5-25, Yogyakarta \\ ${ }^{3}$ verineloerensyah6019@gmail.com
}

\begin{abstract}
Abstrak - Saat ini kita ketahui bahwa seluruh dunia sedang mengalami dampak dari pandemiCOVID-19, baik dari segi ekonomi maupun sosial. Salah satu sektor masyarakat yang terkena dampak ekonomi adalah Persaudaraan Muda-mudi Vihara Dharma Loka (PMVDL) yang berlokasi di Kota Pekanbaru, Provinsi Riau. Banyaknya kerugian secara ekonomi yang didapatkan oleh masyarakat Kota Pekanbaru berdampak pada semakin berkurangnya donatur yang membantu kegiatan keorganisasian PMVDL. Oleh karena itu melalui kegiatan Kuliah Kerja Nyata (KKN) yang dilakukan secara online, Kelompok KKN 68 memberikan program berupa pengenalan teh kombucha dalam rangka memberdayakan masyarakat yang tergabung di PMVDL untuk memulai bisnis secara mandiri sehingga diharapkan dapat meningkatkan perekonomian. Kegiatan yang dilakukan dimulai dari pengenalan dan pembuatan teh kombucha, pengemasan produk agar layak dipasarkan pada platform social media dan perhitungan biaya yang
\end{abstract}

Abstract - The whole world is experiencing the impact of COVID-19 pandemic, both sociallyand financially. One of the sectors of society that is being financially affected is the Youth Brotherhood of Vihara Dharma Loka (PMVDL) which is located in Pekanbaru City, Riau Province. Financial decrease of Pekanbaru society cause indeclining the financial donors to support PMVDL organizational activities. Therefore, through the online community service program (KKN), Group 68 offered a program about dibutuhkan dalam proses produksi sehingga masyarakat mengetahui keuntungan yang diperoleh dari bisnis tersebut. Kegiatan ini dilakukan melalui seminar online dan pemantauan praktek pembuatan produk secara mandiri yang dilakukan oleh anggota PMVDL. Hasil akhir yang didapatkan yaitu produk teh kombucha yang diproduksi dan dibranding oleh peserta, terbentuknya akun Instagram Ads. sebagai sarana promosi online, serta adanya rancangan buku anggaran. Keterlibatan pesertasecara aktif serta antusiasme dalam pelaksanaan program menunjukkan bahwa kegiatan yang dilakukan oleh Kelompok KKN 68 dapat diterima dengan baik sertamemberikan manfaat sebagai salah satu ide bisnis di masa pandemi untuk mengatasi permasalahan ekonomi.

Kata kunci-Teh kombucha, Vihara Dharma Loka, persaudaraan mda-mudi, KKN online.

kombucha tea in order to empower the community in PMVDL to start their own business independently, so it is expected to improve the economy. The scope of the activities including introduction and process of making kombucha tea, packaging and branding for social media marketing, and calculation ofproduction cost to inform the profit of this business. All activities were carried out by online seminar and monitoring was done to know the progress during kombucha tea production. Kombucha tea with brand from PMVDL, Instagram Ads. account to promote 
the product, and book to plan the budget were successfully produced. Participants were actively participated during the program. Thus, indicated that kombucha tea production can be one of the alternatives to start business during pandemic to solve financial problems.

Keywords-Kombucha tea, Vihara Dharma Loka, youth brotherhood, online community service program.

\section{Pendahuluan}

Pandemi Covid-19 memaksa dunia untuk berubah dengan mempengaruhi berbagai macam sektor dunia baik dari segi finansial maupun segi social [1]. Dampak terhadap segi finansial dan sosial ini juga dirasakan di Indonesia yang ditunjukkan dengan penurunan kondisi perekonomian masyarakat [2] [3]. Lingkungan pendidikan juga merupakan salah satu bagian dari sektor sosial yang terkena dampak berat dari pandemi ini [4]. Sejak dimulainya pandemi covid-19 di awal tahun 2020, semua murid dari taman kanak-kanak sampai mahasiswa dipaksa untuk mengikuti sekolah secara daring sehingga menyulitkan para siswa untuk melakukan kegiatankegiatan sosial seperti salah satunya Kuliah Kerja Nyata (KKN) [5] [6].

Kuliah Kerja Nyata (KKN) merupakan salah satu kegiatan wajib bagi mahasiswa di sekolah tinggi yang bertujuan untuk memberikan pengabdian kepada masyarakat. Namun, dengan adanya pandemi yang sedang berlangsung, mahasiswa tidak bisa terjun langsung ke dalam masyarakat seperti tahun-tahun sebelumnya, oleh sebab itu KKN kali ini dilakukan secara daring. Salah satu kegiatan KKN di Universitas Kristen Duta Wacana (UKDW) pada tahun ini adalah dengan memperkenalkan teh kombucha kepada masyarakat Persaudaraan Mudamudi Vihara Dharma Loka (PMVDL) [7].

Dengan adanya pandemi Covid-19 yang sedang berlangsung, PMVDL juga tidak luput dari krisis ekonomi dan membutuhkan dana untuk melakukan kegiatan, oleh karena itu tim KKN peneliti membantu untuk melakukan pemberdayaan para anggota PMVDL supaya bisa memulai bisnis mandiri dengan cara membuat suatu produk yang layak diperjual-belikan oleh mereka yaitu teh kombucha.

Teh kombucha dipilih karena selain memiliki khasiat yang baik bagi kesehatan [8], proses membuatnya pun mudah dan memiliki rasa yang segar dan unik sehingga diharapkan dapat menarik minat masyarakat PekanbaruRiau dan menjadikannya sebagai peluang bisnis yang bagus.

\section{METODE PELAKSANAAN}

\section{A. Persiapan kegiatan}

Persiapan kegiatan dilakukan secara daring dengan bimbingan dari Dosen Pendamping Lapangan (DPL) dan juga Asisten Pendamping Lapangan (APL) mengggunakan aplikasi Google Meet.

\section{B. Penentuan lokasi program}

Setelah berdiskusi dengan DPL serta APL, Kelompok 68 memutuskan untuk memberdayakan SDM PMVDL untuk membuat suatu produk yang layak diperjual belikan di masyarakat Pekanbaru-Riau, yaitu teh kombucha. Teh kombucha dipilih karena selain memiliki khasiat yang sangat baik bagi kesehatan juga proses pembuatannya yang sangat mudah, serta memiliki rasa yang unik dan segar.

\section{Pelaksanaan pelatihan pembuatan produk kombucha}

Tim KKN mandiri kelompok 68 di Kota Pekanbaru Riau melaksanakan program dengan judul "Program pelatihan pemberdayaan \& peluang bisnis teh kombucha bagi masyarakat Persaudaraan Muda - mudi Vihara Dharma Loka Kota Pekanbaru - Riau”. Program yang ditawarkan berupa beberapa usulan program kerja individu dan disampaikan secara teori yaitu seperti pemberian materi secara teknis, kiat-kiat dan solusi dalam pembuatan, disertai dengan praktek langsung oleh masyarakat dengan bimbingan secara online.

\section{Promosi dan dokumentasi}

Kelompok 68 membuat poster untuk mengajak masyarakat pada umumnya dan anggota PMVDL pada khususnya supaya berpartisipasi dalam kegiatan KKN ini. Bagi masyarakat yang ingin melihat bagaimana kegiatan KKN Kelompok 68 berlangsung, dapat mengikuti video yang telah diunggah di Youtube Channel kelompok.

\section{PELAKSANAAN PROGRAM}

Program pelatihan pemberdayaan dan peluang bisnis teh kombucha dilaksanakan melalui seminar secara daring dengan menggabungkan ketiga program individu dari setiap anggota kelompok 68. Metode pelaksanaan seminar di bagi menjadi beberapa sesi dengan menggunakan platform google meet, dimana setiap sesi tersebut masyarakat yang bergabung pada seminar ini akan memperoleh luaran berupa pengetahuan seputar pembuatan teh kombucha hingga menjadi produk yang layak dipasarkan. Pada sesi pertama dibahas topik mengenai proses pembuatan teh kombucha, dimana disediakan bahan - bahan yang diperlukan untuk pembuatan teh kombucha diantaranya scobby, teh, lemon, dll. bagi peserta. Selain itu juga diberikan juga buku panduan untuk proses pembuatan. Kegiatan sesi kedua membahas kegiatan branding pada produk minuman kombucha sehingga memiliki nilai jual di pasaran, dengan bahan yang disediakan untuk masyarakat berupa stiker dan botol kaca. Sesi kegiatan yang masyarakat diajari untuk merancang dan mengelola anggaran pembuatan 
hinga pemasaran dengan disediakan buku anggaran. Hal ini bertujuan untuk membantu masyarakat dalam mengontrol serta nantinya pada pemasaran produk melalui platform sosial media.

Kelompok 68 terdiri dari 3 mahasiswa Universitas Kristen Duta Wacana angkatan 2018 dengan prodi serta fakultas yang berbeda sehingga setiap proker individu dirancang berhubungan satu sama lain. Maka, muncullah seminar pelatihan pemberdayaan dan peluang bisnis teh kombucha yang berlokasi di Kota Pekanbaru - Riau. Segala bentuk kegiatan didokumenasikan melalui Channel Youtube Kelompok KKN 68 seperti pada Gambar 1 yang dapat diakses pada tautan KKN NUSANTARA UKDW 2021 Kelompok 68 - YouTube. Gambar 2. menunjukkan poster kegiatan KKN Kelompok 68.

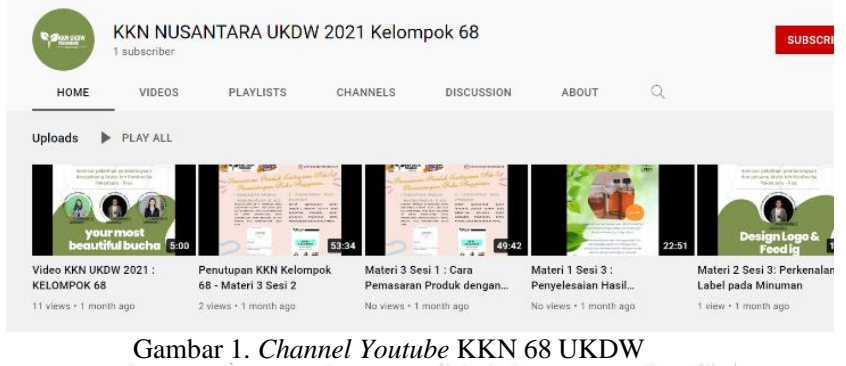

() f |kkn.ukdw.2021.pekanbaru.68

Seminar pelatihan pemberdayaan dan peluang bisnis teh Kombucha Pekanbaru - Riau

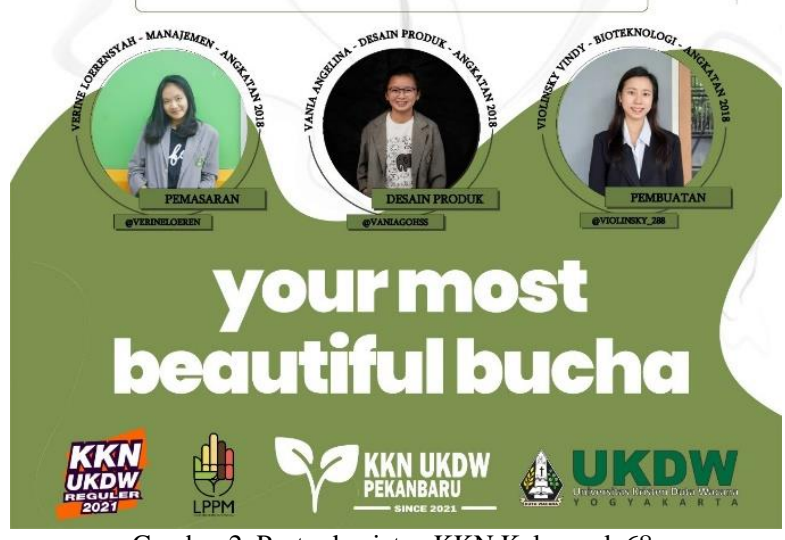

Gambar 2. Poster kegiatan KKN Kelompok 68

\section{A. Pembuatan teh kombucha}

Pada proses pembuatan kombucha ini, para peserta diharapkan dapat membuat teh kombucha secara mandiri sehingga dapat dipasarkan. Kegiatan ini dilakukan secara daring serta melakukan kegiatan praktik secara langsung dengan bahan yang sudah disediakan oleh tim KKN kelompok 68. Bahan-bahan yang disediakan diantaranya adalah scobby yang merupakan starter pembuatan teh kombucha [9]. Pada saat pelaksanaan program pembuatan teh kombucha peserta menyediakan toples dengan ukuran yang cukup besar yaitu kurang lebih 1-2 Liter. Proses pembuatan dilakukan oleh peserta dengan melihat video proses pembuatan yang telah dibuat oleh Kelompok 68. Selama kegiatan berlangsung, antara peserta dengan anggota KKN tetap melakukan komunikasi secara daring untuk membantu mengatasi kesulitan yang dihadapi oleh peserta.

Selama kegiatan, untuk mengetahui apakah masyarakat mengalami kesulitan dalam proses pembuatan teh kombucha, maka anggota kelompok meminta foto keberhasilan produk yang telah dibuat dan kemudian meminta komentar dari seluruh peserta tentang rasa dan juga penampakan akhir dari teh tersebut. Proses pembuatan serta produk yang dihasilkan dapat dilihat pada Gambar 3.

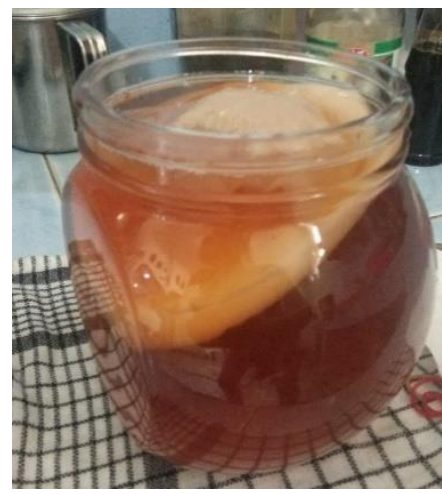

Gambar 3. Produk teh kombucha oleh anggota PMVDL

\section{B. Branding produk}

Kegiatan branding bertujuan untuk meningkatkan nilai jual produk akhir [10] sehingga diharapkan dapat membantu perekonomian organisasi PMVDL. Kegiatan yang dilakukan berupa pembahasan serta pembuatan desain pengemasan produk yang dilakukan oleh peserta dengan bimbingan anggota KKN 68. Produk akhir dipasarkan secara online contohnya melalui sosial media seperti Instagram yang pembuatannya dibantu oleh Kelompok KKN. Poster kegiatan branding dapat dilihat paa Gambar 4. 


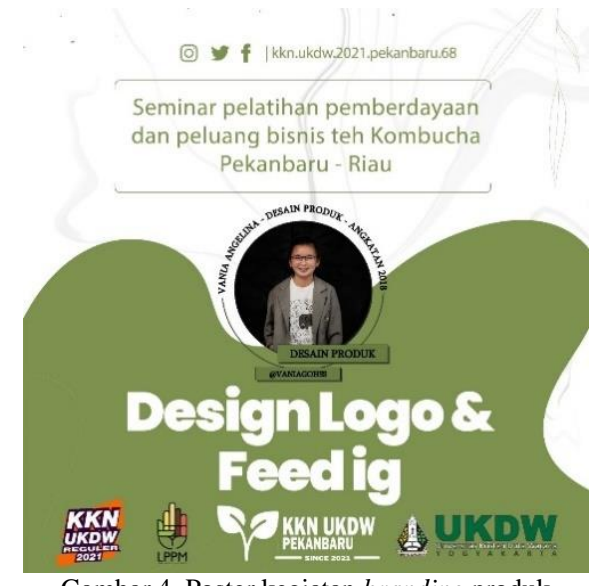

Gambar 4. Poster kegiatan branding produk

Pada saat kegiaan ini dilakukan, para peserta tidak terlalu aktif dalam bertanya sehingga menyulitkan anggota KKN untuk memahami seberapa jauh masyarakat paham mengenai cara-cara branding dan pemasaran produk. Kelompok 68 mensiasatinya dengan menyediakan video youtube mengenai cara mendesain logo dan media sosial menggunakan aplikasi Canva supaya masyarakat dapat menonton kembali jika membutuhkan. Selain pembuatan logo, masyarakat juga diajarkan cara pembuatan feeds Instagram yang dapat menarik calon pembeli. Logo yang telah dibuat dapat dilihat pada Gambar 5.

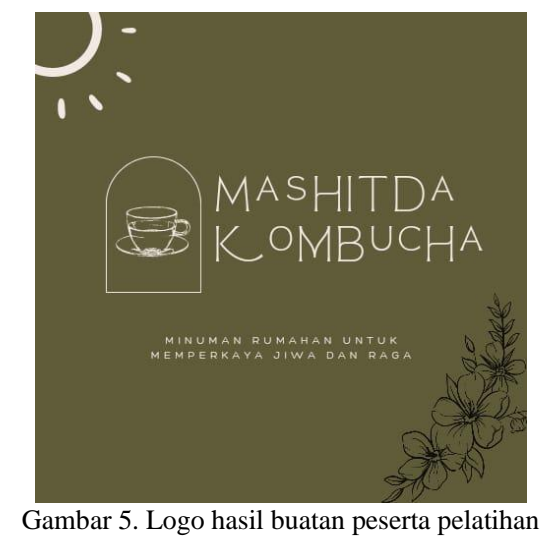

\section{Pelatihan cara pemasaran dan perancangan anggaran usaha}

Kegiatan pelatihan untuk pemasaran produk dilakukan dengan membuat akun media social berupa Instagram yaitu Ig Ads. dengan feeds berupa kegiatan serta pemasaran produk seperti terlihat pada Gambar 6.

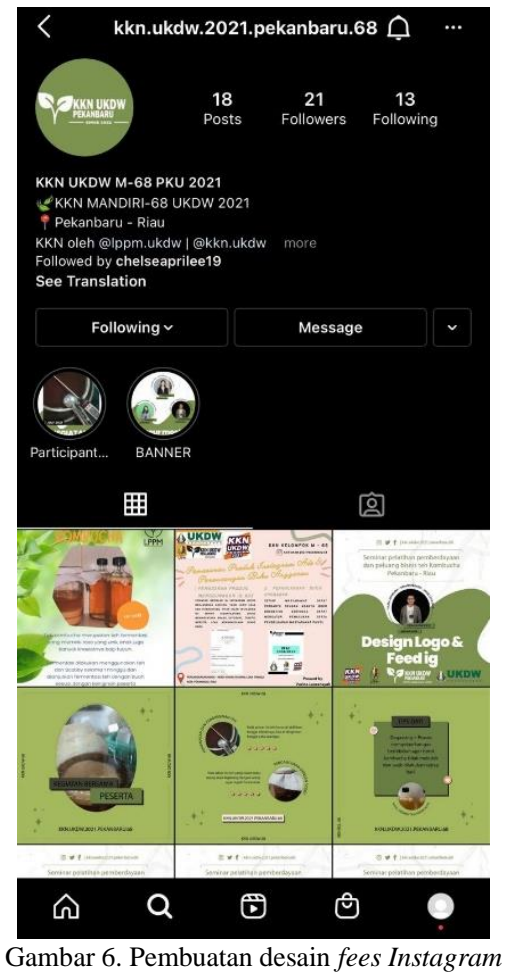

Kegiatan pelatihan juga disertai dengan pemberian materi oleh anggota Kelompok KKN 68 mengenai perancangan buku anggaran usaha scara daring dengan mengadakan pertemuan melalui Google meet. Penjelasan meliputi pengajaran serta penjelasan komponen apa saja yang termasuk ke dalam modal lancer dan juga biaya tetap yang akan ditotalkan menjadi biaya pengeluaran sehingga masyarakat kemudian dapat menentukan harga jual yang sesuai [11]. Poster kegiatan dapat dlihat pada Gambar 7. serta hasil pelatihan buku anggaran usaha dapat dilihat pada Gambar 8.

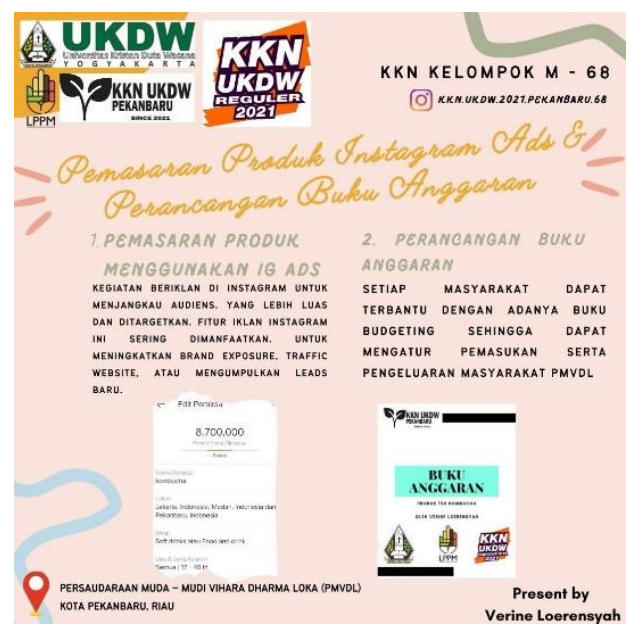

Gambar 7. Poster kegiatan pelatihan cara pemasaran dan perancangan anggaran 


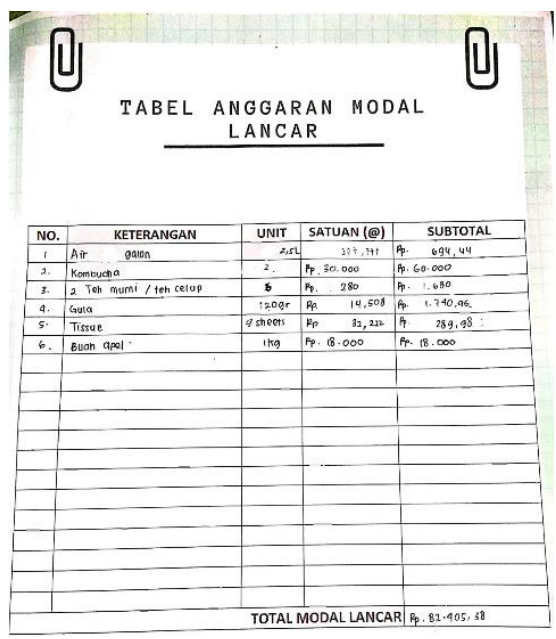

Gambar 8. Hasil perancangan buku anggaran

\section{KESIMPULAN}

Program pembuatan teh kombucha, branding produk, pengajaran pemasaran dan pembuatan anggaran keuangan telah berhasil terlaksana terbukti dengan partisipasi akif peserta an ada luaran berupa produk jadi hasil pelatihan. Hal ini diharapkan dapat menaikan perekonomian masyarakat PMVDL kota Pekanbaru-Riau.

\section{UCAPAN TERIMA KASIH}

Ucapan terimakasih ditujukan kepada Lembaga Penelitian dan Pengabdian Masyarakat (LPPM) Universitas Kristen Duta Wacana Yogyakarta dan anggota Persaudaraan Muda-mudi Vihara Dharma Loka, Kota Pekanbaru-Riau selaku mitra kerja program KKN Kelompok 68.
[1] Sayuti, R. H. dan Hidayati, S. A. "Dampak Pandemi Covid-19 Terhadap Ekonomi Masyarakat di Nusa Tenggara Barat," Resiprokal. vol. 2, no. 2, pp. 133-150, 2020.

[2] Kurniasih, E. P. "Dampak Pandemi Covid 19 Terhadap Penurunan Kesejahteraan Masyarakat Kota Pontianak," Prosiding Seminar Akademik Tahunan Ilmu Ekonomi dan Studi Pembangunan, 2020.

[3] Junaedi, D. dan Salistia, F. "Dampak Pandemi Covid-19 Terhadap Pertumbuhan Ekonomi Negara-negara Terdampak," Simposium Nasional Keuangan Negara. pp. 995, 2020.

[4] Aji R. H. S. "Dampak Covid-19 pada Pendidikan di Indonesia: Sekolah, Keterampilan, dan Proses Pembelajaran," SALAM; Jurnal Sosial \& Budaya Syar-I, vol. 7, no. 5, pp. 395-402, 2020.

[5] Nasution, D. A. D., Erlina dan Muda, I. "Dampak Pandemi Covid19 Terhadap Perekonomian Indonesia,” Jurnal Benefita. vol. 5, no. 2, pp. 212-224, 2020.

[6] Dewi, W. A. "Dampak Pandemi Covid-19 Terhadap Implementas Pembelajaran Daring di Sekolah Dasar," Edukatif: Jurnal Ilmu Pendidikan, 2020.

[7] Siahaan, M. "Dampak Pandemi Covid-19 Terhadap Dunia Pendidikan”, Jurnal Kajan Ilmiah, no. 1, pp. 1-3, 2020.

[8] Khaerah, A. dan Akbar, F. “Aktivitas Antioksidan Teh Kombucha dari Beberapa Varian The yang Berbeda," Prosiding Seminar Nasional LP2M UNM, 2019.

[9] Wistiana, D. dan Zubaidah, E. "Karakteristik Kimiawi dan Mikrobiologis Kombucha dan Berbagai Daun Tinggi Fenol Selama Fermentasi," Jurnal Pangan dan Agroindustri, vol. 3, no. 4, pp. 1446-1457, 2015.

[10] Diarta, I. K. S., Lestari, P. W. dan Dewi, I. A. P. C. "Strategi Branding dalam Promosi Penjualan Produk Pertanian Olahan PT. Hatten Bali untuk Pasar Pariwisata Indonesia," Jurnal Manajemen Agribisnis, vol. 4, no. 2, pp. 170-187, 2016.

[11] Herlianto, D. "Teknik Penyusunan Anggaran Operasional Perusahaan,” Gosyen Publishing, cetakan pertama, 2011.

\section{DAFTAR PUSTAKA}

